International Research Journal of Management, IT \& Social Sciences
Available online at https://sloap.org/journals/index.php/irjmis/
Vol. 7 No. 2, March 2020, pages: 59-70
ISSN: 2395-7492
https://doi.org/10.21744/irjmis.v7n2.878

\title{
Hedonism on the behavior of consumer society as a global cultural transformation
}

\begin{tabular}{|c|c|}
\hline & $\begin{array}{r}\text { Nyoman Sri Subawa } \\
\text { Ni Wayan Widhiasthini } \\
{ }^{\mathrm{b}} \\
\text { Putu Ayu Titha Paramita Pika } \\
\text { Putu Indah Suryawati }\end{array}$ \\
\hline rticle history: & Abstract \\
\hline $\begin{array}{l}\text { Submitted: } 09 \text { January } 2020 \\
\text { Revised: } 27 \text { February } 2020 \\
\text { Accepted: } 18 \text { March } 2020\end{array}$ & $\begin{array}{l}\text { This study deals with changes in consumer behavior based on hedonic desires. } \\
\text { The change from consumption to consumerism. This is done on the purchase } \\
\text { of four-wheeled vehicles (cars). This research is expected to provide awareness } \\
\text { and critical understanding to the public to buy products according to their } \\
\text { abilities, not get caught in the capitalist trap. This study uses descriptive } \\
\text { qualitative and interpretive, by involving consumers, car marketers, and }\end{array}$ \\
\hline $\begin{array}{l}\text { Keywords: } \\
\text { consumer behavior; } \\
\text { consumerism; } \\
\text { global cultural transformation; }\end{array}$ & $\begin{array}{l}\text { financial agents as informants. The results show that there has been a } \\
\text { transformation in the behavior of consumer societies based on the desire of } \\
\text { hedonism that is influenced by global cultural imperialism, such as instant } \\
\text { culture and consumerism behavior. Further research needs to be done on } \\
\text { consumers in excessive consumption of other products. }\end{array}$ \\
\hline
\end{tabular}

hedonism;

social change;

International research journal of management, IT and social sciences (C) 2020.

This is an open access article under the CC BY-NC-ND license

(https://creativecommons.org/licenses/by-nc-nd/4.0/).

Corresponding author:

Nyoman Sri Subawa,

Universitas Pendidikan Nasional, Denpasar, Indonesia.

Email address: shribawa@undiknas.ac.id

\footnotetext{
a Universitas Pendidikan Nasional, Denpasar, Indonesia

${ }^{\mathrm{b}}$ Universitas Pendidikan Nasional, Denpasar, Indonesia

Universitas Pendidikan Nasional, Denpasar, Indonesia

${ }^{\mathrm{d}}$ Universitas Pendidikan Nasional, Denpasar, Indonesia
} 


\section{Introduction}

The current development of the global culture that has been plagued so powerful and touched different sides of people's lives. On economics, the social change that occurred in the community is very strong, especially on the behavior of consumption of goods and services. Consumption as presented by Rosyidi (2006), that consumption is used goods and services in the satisfactions of human wants). Büttner \& Göritz (2008), argued that individuals might use consumption as a way to manage and regulate their emotions. Over time development, one of which is strongly influenced by the postmodern era, the consumption pattern had changed from just doing consumption, into the act of consumption by considering the value and meaning of each of the goods and services they consume. Changes in consumption patterns that lead to the people trapped in consumption patterns tend to be excessive, such as buying goods which were not needed, consuming goods and services due to consider the value and the meaning contained in such a product, and a variety of other consumer actions. Communities do practice consumption as mentioned differences, called consumer society. The fact is that 'society is consumptive, the enthusiasm they demonstrated with responding to the presence of new products to be launched, such as the four-wheeled vehicles that tend to be purchased at a price that is quite expensive. Consumption of goods and services, especially luxury goods such as four-wheeled vehicles, has become an important lifestyle choice for consumers to display wealth, acquire social status, and seek uniqueness (Shao et al., 2019). Another researcher also argues that many consumers buy luxury goods to convey their level of prestige, boost self-esteem, and express their identity (Han et al., 2010).

Data support expressed by Bappenas, that household consumption for non-food consumption is greater than in food consumption, in 2011 the consumption of non-foods by 5.5\%, while the food of 3.5\% (Bappenas, Directorate of Macro Planning, 2011). If examined frequently purchased items tend to not necessary, because they generally have all these items even numbers could be more than one. When deciding to buy a new car, the actual goods are not needed because in the garage of their home had provided two or even three or four cars with different brands and types. At this point the blandishments of capitalism through the middle of the storm packing advertising community.

Consumer society is synonymous with consumerism, Storey (1996), classifies consumerism as an understanding (ideology), it is certainly based on differences gluing word "ism" as a suffix word, that the ideology of consumerism is the suggestion that the meaning of a person's life to be found in something that is consumed, not on something produced. Referring to the concept shows that the public trapped in the idea of consumerism encourages them to buy all kinds of products with no control. It was based on a desire embedded in a person that is hedonism, which is triggered by Campbell (as cited in Ibrahim, 2004) as "the desire to bring the pleasures created and employed through imagination into reality. Desire is what causes the consumption unceasing practice to something new". Whereas Hirschman \& Holbrook (1982), described hedonism as the consumer behavior which relates to the multisensory, fantasy, and emotive aspects of one's experience with products. Hedonic consumption based on (Zhong \& Mitchell, 2010), was described as the indirect effects on well-being, by improving the satisfaction of consumers within life domains.

The phenomenon of consumerism based on hedonism as described above is an empirical phenomenon. Related rules of science can be stated that the consumerism associated and also contrary to the core concept of "needs, desires, and demands" are legal in marketing management. Kotler \& Keller (2009), states that a requirement of basic human needs, while shaped by the desire of one's community, while the demand is a desire for specific products backed by the ability to pay. Consumerism behavior can be explained that someone may develop because of the influence of the environment so that it was related to the concept of desire. In addition to environmental influences, consumerism also is triggered by other factors in the external environment, where it will be studied further in this study. Meanwhile, related to the concept of demand, then consumerism is contrary to the concept, that someone buys specific products that are always supported by the ability to pay. But in reality, the practice of consumerism causes someone does the demand for goods and services are often not supported by the ability to pay, they are important: the act of buying is based on various factors. The factors could include facilities for obtaining loans on the condition that is a lightweight, strong influence of the surrounding environment, the strength of the hegemony of advertising through mass media, or other causal factors, which could become the cornerstone of society in practice consumerism.

Another interesting thing to observe is the emergence of an understanding of the values that you want to target the consumer society in the practice of consumerism, which certainly is associated with hedonism. The people buy not because it needs the goods or services, but to reach the value contained on a product. Such as increased prestige in the social environment, he achieved certain imaging, the strength of the prestige, and also other values inherent, beginning of the process until the ownership of a product. These factors will be discussed and examined in-depth, to serve as the findings and urgency targeted in this study. Referring to these two problems that can be formulated in this research is how the practical realities of hedonism that occurred in the behavior of the consumer society as a global cultural 
transformation. This study aims to contribute to the development of science, especially in the field of social and humanities related to the practice of public consumption lately tends to be excessive, so there has been a change in consumption patterns.

The findings were targeted in this study and were primarily related to the rules of science which is the application of concepts and theoretical components. Component concepts and theories applicable and generally recognized, cannot be applied in full in this study, or the application of concepts and theories that exceeds that of the components that have been there before. One that can be exemplified is the concept of needs, desires, and demands put forward Kotler and Keller. The concept was original could explain the pattern of consumption, but as the dynamics of the growing consumerism in the society is deemed necessary concepts tested, juxtaposed with the reality of the findings obtained in the research arena. Moving on from the research findings are expected to arise new understanding in the field of socio-economic, as follows. First, there has been a practice of consumerism conducted by consumer society based on hedonism. There has been a shift in consumption patterns were made public, of consumption according to the goods and services required, now turned into a consumer society by making the consumption of excessive caused by various factors such as lifestyle, the influence of the media, game networking capitalism through easy credit, and stimulus spending through various means. Second, bring awareness to the consumer society that does not always get caught up in excessive consumption the Other Construction that is deliberately created, built and developed by the economic actors who gathered in networking capitalism.

\section{Literature Review}

Consumer behavior is one of the marketing theory where individual aspirations and motivations play important roles (Truong \& McColl, 2011). Based on searches you've done, there are previous studies that have relevance to this study, the research has done Subawa (2016), review of consumer behavior in consuming perfume has given meaning social class, lifestyle, value and psychological pricing, and prestige. Had an exchange of economic capital, social, cultural and symbolic capital to achieve for consumers. Later studies by Widhiasthini (2006), the study revealed that consumerism has become a culture, practiced by almost every stratum of society with diverse reasons, in which the role of the media is very important. As a culture, the practice of consumerism is like as an everyday activity that equal treatment with other cultural activities. Other related research also is carried out by Subawa (2015), who described that hedonism is an ongoing phenomenon, is that permeated contemporary global society. Research conducted by Semaan et al. (2019), also found that indulgence or hedonism is one of the drivers of luxury consumption which described by emotional benefit. Hedonism (Sheth et al., 1991), was described as the state in which consumers seek products for their intrinsically appealing properties and subjective emotional benefits. So, hedonic motives could lead an individual to buy goods or services for pleasure and/or enjoyment ( $\mathrm{G} \tilde{\mathrm{A}} 1 / 4$ ltekin, 2012), esthetic beauty, excitement, arousing feelings, and affective states receiving personal rewards and fulfillment (Schade et al., 2016). Hedonism has also become an integral part of the lifestyle, where the community requires him constantly updating the product range so that it gave birth to the nature of hedonism. All the above results inspire researchers to learn more about the behavior of consumerism society, which is heavily influenced by the desire hedonism. There are similarities with the research that will be done is equally raised the issue of consumerism, and refers specifically to products consumed as consumer behavior of society, namely perfume and car.

\section{Materials and Methods}

The method used in this research was a qualitative method, by aligning multiple disciplines. Object and subject of research was the consumer society, in this study there was no distance between the researcher with the object and subject of research. Denpasar city designated as the study site because the city is a global city, located within the territory of the Province of Bali which has been recognized as a world tourism destination, the administrative center and also one of the major cities in Indonesia. Economic growth and the purchasing power of people in Denpasar is also quite high, so there are many well-known brand sales agents are classified as transnational companies such as Toyota, Honda, Mitsubishi, Chevrolet, Mazda, BMW, Nissan, and other brands.

The data used were the quantitative and qualitative data, as well as primary and secondary data sources. Data collection techniques in this study, include observation, interview and document study. Observations were made directly by observing the object of research by the researchers, the behavior of domestic consumption of automotive products as part of hedonic behavior. Depth interviews are data collection techniques by interviewing directly with the

Subawa, N. S., Widhiasthini, N. W., Pika, P. A. T. P., \& Suryawati, P. I. (2020). Hedonism on the behavior of consumer society as a global cultural transformation. International Research Journal of Management, IT and Social Sciences, 7(2), 59-70. https://doi.org/10.21744/irjmis.v7n2.878 
informant. This interview aims to collect data/information related to this study conducted in-depth to related parties, such as sales, marketing, manager or managing distributors, and public or consumer vehicles. Items will be examined in this study was four-wheeled vehicles (cars), the grounds of the classified items are not consumable, not a primary need, the price is quite expensive, the producers very often issued a new type that competition among manufacturers and salespeople is very high. The product will also be a wearer to show the existence of self, prestige, and prestige. Informants to the community or the consumers in this study is a well-established community age (aged 40 to 60 years) who has had a steady income, arguing that the group is very generous to spend money to buy the latest products. Interviews were conducted with 10 informants, informants using purposive determination, especially convenience and judgment.

Data were collected, starting from the observation, in-depth interview with the informant and the results of the collection of documents study analyzed descriptively qualitative and interpretative. The results of data processing and is not presented in the form of numbers, the numbers are just as supportive data. The measures undertaken in this study include the stages of data reduction, data presentation, and draw appropriate conclusions opinion of Miles \& Huberman (1992). The framework in this study can be described as follows.

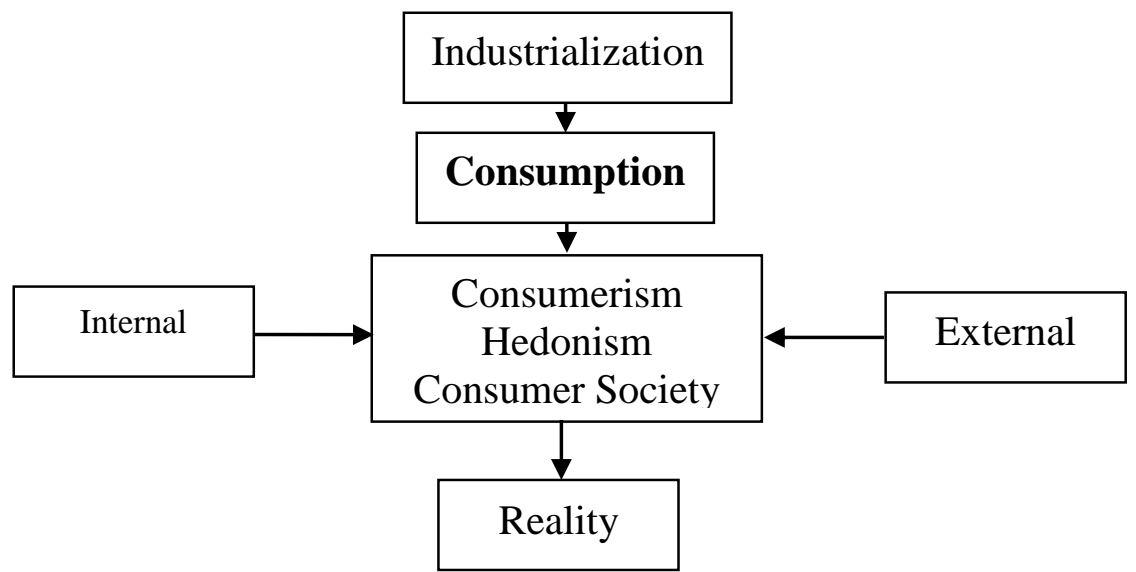

Figure 1 Framework Research

Source: Research Data, 2019

Based on the framework, can be explained that the period of industrialization marked with the mass production of goods and services by the manufacturers trigger consumption. In that era, people do business based on the consumption of subsistence, as well as the value of the usefulness of the product concerned. With time in consumption patterns shift to consumerism is based on the desire of hedonism, it was triggered by internal factors such as age and income as well as external factors such as environmental and other reference groups. After scrutiny of the reality of hedonism in the behavior of the consumer society, it is expected to contribute to the advancement of critical thinking science, society, and employers as economic actors and the government as a regulator.

\section{Results and Discussions}

As the provincial capital of Bali, a tourist destination, the center of government, education center, metropolis and one of the major cities in Indonesia made the economic condition of Denpasar growing very rapidly. Geographically, consists of four areas, namely East Denpasar, Denpasar Selatan, Denpasar, and Denpasar North West, Denpasar become the access to get to the Ngurah Rai International Airport was located in Badung regency. In addition to the Badung, Denpasar city is also within walking distance of Gianyar and Tabanan. Several roads in the area of Denpasar is the access to go to the district.

Population data in Denpasar can be drawn that the population of Denpasar in 2018 amounted to 863600 people, with its economic growth from year to year has increased rapidly, in 2018 targeted economic growth of $6.94 \%$. The distribution of income in Denpasar in 2014 to a low of $13.68 \%$ category, the category was $37.65 \%$ and $48.67 \%$ higher category (Central Bureau of Statistics, 2017). Based on these data it turns out the distribution of income to a higher 
category earned the highest percentage, the condition becomes one reason for the high consumption of consumers in Denpasar on a variety of products including cars.

Consumer behavior in Denpasar to the car high enough cannot be separated from the consumer behavior of consumers Balinese against the car was also very high. The community was very responsive to the presence of various types and models of new cars launched by the manufacturer, sometimes even the type of car that has not been marketed in Bali. They were vying to buy the products newly launched cars are by ordering the dealer, or better known as a pivot. Kleden (2014), said that based on sales data, shows the total car sales in Bali throughout September 2014 as many as 3,417 units, this number has increased sales in August as many as 3,114 units. Denpasar region became the largest contributor throughout September car sales are 1,256 units, followed by 714 units Badung, Gianyar 351 units. The next position Singaraja 303 units, 302 units Tabanan, Karangasem 169 units, 145 units of the State, Bangli, Klungkung last 96 units and 81 units. Interestingly, in addition to being the city of the highest selling car in the province of Bali, Denpasar also turned out a nationwide fifth position. The order of the cities with the highest car sales includes Jakarta, Surabaya, Bandung, Semarang, Denpasar, Medan, Makassar, Yogyakarta, Solo, and Palembang.

As one of the major cities in Indonesia, Denpasar city has a high appeal to the company car dealership to open his business. Almost all companies that hold licenses for sales of car brands such as Toyota, Suzuki, Daihatsu, Mitsubishi, Honda, Isuzu, Nissan, Ford, Mazda, and Kia opened a marketing office in Denpasar. Based on data from autorevindonesia.com rankings Toyota car sales amounted to 1,068 units dominated by Market Share (MS) 31\%, the second position is occupied by 932 units Suzuki MS 27\%, followed by Daihatsu 528 units MS 15\%. The next position each occupied Mitsubishi 273 units MS 8\%, Honda 228 units MS 7\%, Isuzu 86 unit MS 3\%, Nissan 82 units MS 2\%, Ford 50 units MS 1\% and KIA 13 units MS 0\%, while sales of other types 137 units MS 4\%.

Based on these data, it was associated with this research that can be presented on the company profiles of some car dealers that were deemed necessary to serve. His position as representatives of car manufacturers or sole agent covers the province of Bali, also a representation of the automaker itself is positioned to understand the hedonism of consumer society. Especially in his role as drivers of hedonism. The car dealership that will be described is Toyota, Suzuki, and Mitsubishi. PT. Agung Automall was authorized Toyota main dealer for the area of Bali, it is also the area of Riau, Jambi, Bengkulu and Riau Islands. The next car dealer PT. United Indobali Dealers, the dealers for the brand Suzuki. And the third is PT. Bumen Redja Abadi, the namely dealer, manages and markets Mitsubishi brand vehicles. All three were selected dealers and may represent a class of car brands, that sales are at a high level and the expansion of its business is also very fast.

In the activity of marketing its products, the third car dealers on very intensively exhibition. They are opening outlets in shopping centers in the city of Denpasar and Badung like Tiara Dewata, Carrefour, Matahari, Hypermart, Lotte Mart, Lippo Mall, and others known as the family shopping center where customers are from the upper-middle class. On occasion, they displayed various types of vehicles, with a choice of white, black, red or colors that match the color trends that are a popular consumer. Prospective customers are allowed to examine closely the condition of the car so that the various advantages of each type better known by prospective customers. Even guards who are usually called the counter sales also allow potential customers to try and allow testing drive. Besides, various brochures, pamphlets, leaflets were distributed to visitors of the shopping center that usually contains excellence, application, color choices to price and credit facilities that can convince consumers to buy them.

In the process of marketing a car, a very big role held by the dealer who is often referred to as a sales or marketing. They are the spearhead of the dealer in marketing new products, after selecting the location of the exhibition at strategic locations such as shopping centers were crowded, then the task of sales to proactively market the product. The sales agent hereinafter referred to as sales or marketing is very important to be presented. Based on the observations of researchers' age sales ranged between twenty-five years to fifty years, but most of the relatively young age under forty years. Marketing the age of 40 years generally has been a senior, supervisor or sales manager who is in charge of sales in groups or often called a team. Sales mostly male sex, which is in charge of sales in total even with the system pick up the ball. While the female is usually more in charge of sales at the dealer's office called the sales counter. The sales counter is not selling out the office area, but the duty to receive calls and serve consumers who make the initial assessment before deciding to purchase a car. They also serve potential customers who came to the dealership, explain in detail the specifications of the vehicles that consumers demand.

Education of sales, in general, is a bachelor 1, graduates of private universities or abroad and come from a variety of disciplines, but most are economic scholars. The backgrounds of disciplinary are not too be a requirement because the emphasis is their ability to do the marketing, the art of convincing potential customers and knowledge of the products marketed in detail. A high work ethic, the ability to read the sales opportunity, the strength to face stiff competition among sales, good marketing the same products or sales that sell other car brands is largely determined

Subawa, N. S., Widhiasthini, N. W., Pika, P. A. T. P., \& Suryawati, P. I. (2020). Hedonism on the behavior of consumer society as a global cultural transformation. International Research Journal of Management, IT and Social Sciences, 7(2), 59-70. https://doi.org/10.21744/irjmis.v7n2.878 
the amount of income they earn. Income earned by the sales quite high and very varied, in addition to basic salary, their incomes are dependent on the number of units they successfully marketed. Income has termed a type of bonus sales have certainly obtained from the dealer, but it is also of insurance, or financial institution if consumers buy with a credit system. Uniquely the longer credit period is taken by customers, the bonus for higher sales.

An integral component of a car dealership after-sales are financial institutions that provide credit to consumers, or better known as finance. As more and more people are choosing to buy a car with a credit system, the growth of finance in Denpasar is also very high. Today almost all financial institutions lend vehicles, although initially only be done by non-bank financial institutions that are specialized as a financial institution. But now any bank-lending and opened a special office dealing with motor vehicle credit. Not only private banks, state-owned banks also provide financing of the credit. Some are known to the public finance is BII Bank, CIMB Niaga, BRI, BNI, Mandiri Bank, Adira, WOM, FIF, BTPN, Lestari, and much other finance. Competition cannot be avoided, apart from competing to offer interest rates and low down payment, then this finance would not want to cooperate with the sales so that the consumer was led to take the credit on the institution. Compete to provide high bonuses to sales is one of the strategies that do finance. In this case, the role of the sales to convince buyers to take the credit facility of the finance is crucial, so the achievement of the target of credit that must be met finance met. To note very few potential customers who have determined the car buyers to finance a car loan finance to be bought.

\section{Consumer public profile}

Consumer society is one important element in the chain of sales of four-wheeled vehicles. Consumer society is described as one directed largely by the accumulation and consumption of material goods and it is coming from the perception in which a society will inevitably be hedonistic (O'Shaughnessy \& O'Shaughnessy, 2002). Generally, the age of the consumer society was childbearing age, the age established in the range of thirty to sixty years of the age where they are very productive work, and career. Background profession is very diverse from civil servants (Civil Service), army, the police, doctors, lawyers, accountants, notaries, professors, attorneys, professional private companies such as banks, hotels, and successful entrepreneurs such as contractors, spa and various professions more. In terms of income, consumer society is generally stable income above Rp.4.000.000, - (four million rupiahs). They reside in various areas in the city of Denpasar and surrounding areas, to obtain access to information about the various types of a brand new car from a variety of sources. In particular, they obtain information through advertising in the mass media, especially television, billboards, exhibitions, the internet, and other media. This community is a very intense look at the development of the newly launched car, car new output produced by certain brands. According to prior research, two main reasons motivate consumers to buy luxury goods such as the newly launched car. The first reason is social and interpersonal values that create social stratification and signal luxury for others (Godey et al., 2013). Second, there is a very strong and hedonistic component where luxury goods are acquired for oneself rather than others (Vigneron \& Johnson, 2004). Another researcher also argues that based on the self-concept, luxury consumption is driven by interdependent and independent factors (Kastanakis \& Balabanis, 2012). Consumers with interdependent self-concept tend to buy luxury goods as a means of display to others to show the level of wealth and prestige. Whereas consumers with independent self-concept tend to focus on their self-related goals and needs. Consumers buy luxury goods such as cars that are driven by psychological aspects such as hedonistic, utilitarian, selfcommunication, and self-enhancement goals (Kastanakis \& Balabanis, 2012).

In peeling and answer the problems listed in the formulation of research problems, namely the practical realities of hedonism in the behavior of the consumer society. It described the practice of hedonism is a related consumer society as the practice of hedonism, the costs incurred in realizing the desire hedonism, intensity and momentum of new vehicle purchases as well as ways in which the consumer society in realizing the desire hedonism have a vehicle. Citing the concept of consumer society can be underlined that this society is a society that is socially constructed by the capitalists. Before issuing the latest type of car manufacturers have set a course segment of society through research and target market of consumers, such as what the market characteristics that will serve as its sales targets. As performed by Yasa (56 years old) who works as a lecturer, he is fond of persons belonging to purchase various types of a brand new car from a variety of brands. When researchers asked the reason why he so often bought a brand new car, despite the author's knowledge he has had more cars than five pieces, Yasa which also has businesses in the automotive sector have responded as follows.

"I was pleased to join the development of automobile technology, so I'm happy to buy cars new series. For example, Toyota 'Fortuner', I follow the purchase of the first series to the latest generation. The same thing with the Pajero Sport, I've got the first series and now I've been dressing the latest type which is 'tryptonic'. It turns out everything 
is different, and increasingly sophisticated technology, also added aerodynamic shape. Take it slow, guys. I use first if anyone wants to buy at a good price so I was off, if anyone wants to lease yes I rented out. My 'Fortuner' that black is often rented out for events conference ".

Statement informant, Yasa interesting to observe, it was bought a brand new car is part of the hobby is certainly not a need for a tool of transportation, because based on the observations of investigators at his home there are a lot of cars with various types and brands. It certainly fits with the concept of a consumer society Piliang (2011), that everyone is conditioned to seek and find the meaning of life (only) through the act of consumption. In this case, the informant gets satisfaction after he can enjoy and know the technological development of a specific type and brand of the car, which he got to have it now. The informant also uniquely treats his car, in this case, he does not question the cost of maintenance, resale price, the word "take it slow or relax" one who expresses it. Referring to the theoretical foundation that is consistent with the theory of consumer behavior, that person buys influenced by age, occupation, life cycle stage, economic conditions, the personality, the concept, and lifestyle. What does the informant have a close relationship with the theory, the views of his age he was classified as an established age, he is at the stage of maturity, with his job as a lecturer, automotive entrepreneur then from earnings and economic conditions are also very supportive to practice consumerism.

Meanwhile, another informant was Sumadi (28 years) of a marketing than a car dealership that provides answers to the statement that researchers propose relevant public behavior Denpasar and surrounding areas in buying cars in their work, and how consumers are doing buyer, this informant gives the following reply.

"If Balinese was very quick to respond, every new product must be sold, even sometimes not up to Bali for the newly launched existing pivot. Usually, they already had another car in his home, for the first one to buy a car rarely buy new cars. Well if I can ask the info of where they say look at television advertising, fairs, their reason was want to have 'Outlander, or Pajero the new type. For more financing that takes credit now, besides indeed instructions from dealers that sales were told to steer consumers to take any credit. People are also interested in credit for low interest offered finance, insurance covered, just not necessarily the person who bought the car ready cash".

What does the informant increasingly show that someone who buys a car is not a part of their need for transportation, but rather the desire to want to enjoy advance technology and sophisticated features were offered by the producers? In other words, consumers of luxury cars tend to pay more attention to the actual quality of the product and its ability to provide self-directed pleasure (Truong \& McColl, 2011). The desire was necessarily based on the desire of hedonism in him. Another interesting thing that people are buying more new cars that utilize credit facilities that are offered by the dealer through a variety of finance. Although not necessarily true also those who buy on credit do not have cash for a car offer. But because they are attracted by the low mortgage interest, insurance coverage as promised by dealers. In this condition the marketing in particular, and of course dealers are benefited please work place. Because they got a bonus of more than finance on credit customers that they managed to convince. This condition is following the opinion of Lim (2014), which says that the quality of service, servicescape, exclusivity, brand, and personalized positively related to customer hedonism. Furthermore, hedonism positively influences customer satisfaction and perceived value so positively also affects consumer behavior intention to consume the product. Lim opinion that justifies if that happens to a consumer who had never enjoyed the sophistication of cars offered by manufacturers, so consumers tend to perpetuate the practice of consumerism based on hedonism through the act of buying back products more sophisticated kind offered by the manufacturer.

Theoretically, this is following the Theory of Social Change, which is the difference at different times in the same system. It can be explained that over time, people who buy a car on credit is common, unlike the last time when the stigma for people who buy on credit is not well off financially. Besides the use of the theory of hegemony is also very visible, strong hegemony conducted by marketing to buyers to take credit facility is a multilevel hegemony obtained from the dealer.

The magnitude of the costs incurred for new vehicle purchases by consumers, it is varied depending on the type and brand of cars, each of which has its advantages.

"Consumers are often instead of a car with the latest output usually doctors, employees of banks, notary or young mothers, college kids as well. If now almost all the ordinary professions replace a car, different from before the 2000 s did the medical profession most often grab the new car. Now consumers in Bali was easy once interested in the latest output type, another trend white cars they replace the white, they immediately launched a new type of pivot. For their payments sufficient to pay an advance of their remaining installment in finance".

Subawa, N. S., Widhiasthini, N. W., Pika, P. A. T. P., \& Suryawati, P. I. (2020). Hedonism on the behavior of consumer society as a global cultural transformation. International Research Journal of Management, IT and Social Sciences, 7(2), 59-70. https://doi.org/10.21744/irjmis.v7n2.878 
The above was stated by Artho, a marketing supervisor of a car dealership when the author asked of any profession most often buy new cars sold by dealers where she worked. The answer shows a shift in consumer behavior in buying a new car, that before the year 2000 is limited to only certain professions who like change, change cars to buy a new car. But now, almost all people are used to buy new cars, they are even more who buy on credit. If it is associated with the theory of consumer behavior theory, it seems relevant to this reality that in buying a person is influenced by personal factors, a person is also influenced by age and life cycle stage, occupation, economic circumstances, lifestyle, personality, and concepts. As well as psychological factors, consist of motivation, perception, learning, beliefs, and attitudes. In different periods of the community also make purchases of the new car is not only limited to certain professions.

In connection with the number of people who buy new cars through credit programs, researchers asked how the reality of consumption of new car loans offered by financial institutions to 'Gus Arsa', a special government bank staff to handle a motor vehicle credit. Here is the answer.

\begin{abstract}
"Yes, now a variety of reasons people take credit, there was indeed a shortage of funds but they want to buy a new car, there are also who want to focus their income devoted to paying the mortgage. Or there are funds allocated also to credit other goods, such as home loans, gold, or the other. It may be said of people who take credit did not necessarily have the money. Our bank credit is aggressively marketing to the public, we usually sign-ins to government and private offices, plus a marketing program created by the central office in cooperation with car dealers of various brands".
\end{abstract}

The expression informant asserted that buying a car on credit is now becoming a common practice community, with various reasons and considerations. Observations researchers with buying a car on credit also to the community are getting a wide range of facilities, such as vehicle insurance, payment discount that is often termed cashback even number could reach 40 million and still be negotiated to get more discount. Unlike the purchase without credit, the consumer just does not get any bonus. At this point that was visible capitalism networking gameplay its role, the marketer more than happy to direct consumers to buy on credit because they got a bonus of finance. It shows various facilities given by either party dealers, finance and other networks to show the form of services provided to consumers. Services, facilities, and services will have an impact on the continuity of the customer to do and make choices, transact and consume constantly. In harmony with the research conducted by Mansouri \& Taherikia (2015), which shows that the quality of service, the pleasure and the passion of a relationship positive and significant impact on customer loyalty to consume. The results of the discussion also showed loyalty and passion have a significant and positive relationship with the customer and are willing to pay more.

Cite research from Loureiro \& Araujo (2014), states that the individual scores positively affect consumption intentions, and negatively affect the control behavior in consuming luxury goods. This means that consumers have a pattern and lifestyle and values held in consumer goods that are more concerned with the value of the products offered. Economic value denoted consumers' willingness to pay luxury goods and services (Jain, 2019). Similarly, in this study were more focused on psychological prestige, luxury, and personal status bears. The behavior to consume continuously into the lifestyle, choice, and motivation towards luxury goods (cars are always changing). This raises the emotional value of continuing to consume. Opinion from Malone et al. (2014), which states experience high emotional motivate ethical choices of consumers. Wiedmann et al. (2007), also argued that positive emotions feel by individuals leads to hedonic experiences which then results in personal motivations of luxury consumption. Hedonism's role in rationalizing and strengthening the ethical behavior of individuals. Further revealed that the emotional experience as a source of value for the individual in the act hedonic consumption.

The theory of hegemony is a theory that is very relevant to the reality of what happened in the community, that the hallmark of hegemony by Ratna (2007), is the dominance of one class against another, based on leadership so that the class dominated accept it voluntarily, as true, naturally, in addition to common-sense. Hegemony is much more robust and powerful than the other forms of force because it is not limited by space and time. Related to this study, the elements involved are party hegemony, namely the public and the actors of hegemony were economic actors and their networks capitalism. Behavior dealer in providing convenience, persuasion, motivation, and stimuli in the form of credit is also a form of hegemony over the consumer. Unwittingly, the "consumer" has been acting and doing actual consumption they do not need. It is also affected by hegemony ads that seem indulgent consumers and eliminate rational in consuming the product. Ad into an external stimulus on the consumers themselves, so keen and decisive in the choice of brand, products purchased, pricing options, and where they buy it. Advertising patterns shown in the media provide color and appeal to consumers in the form of print, audio, visual and audio digital or electronic media available. Advertising actions show the passion and the greater the motivation of consumers to consume goods. This 
means that the ads more often advertise, then the level of consumption of the larger product made by consumers. Advertising provides a positive effect on consumers.

\section{Transformation of global culture and society consumer behavior}

While the discussion related to global cultural transformation is also a very interesting thing, which has brought major changes in consumer behavior, lifestyles and customs of the people such as the creation of an instant culture that causes people to want to do and get things in a way that is quick and easy. Siu et al. (2016), also argued that national culture could influence the way consumers perceive and value luxury goods and services. According to Teimourpour $\&$ Hanzaee (2011), culture has been seen as an important influence on human behavior where an individual's behavior is usually reflective of their cultural value system. Through a wide selection of convenience offered by the car dealer, the public can make their choice freely. "Credit Process just one day" is the tagline that is often used by marketing and finance to convince consumers who want to own a car by using credit facilities. In connection with this, a supervisor at the company, was 'Yudana' car dealer revealed the following statement.

"We are always delivered to prospective customers, regardless of the advances that father or mother have, we will adjust the monthly installments so that they do not hesitate to take the credit".

Some consumers, new car buyers also provides marketing data is that the car dealer finance in cooperation with highly accommodating financial conditions of consumers, in the sense that they will adjust the monthly installment payment obligations paid by consumers, about the size of the down payment paid. It is recognized by consumers as 'Wayan, Tya, and Pande' who has had a car with a credit method. Based on the observations of researchers, the speed of the process of credit analysis that has been applied by banks and finance companies are also the main attraction of consumers to have a car with the credit system. Through the requirements are not too difficult as the family card, salary slips, passbooks, and identity cards, the credit analyst will survey the condition of the prospective lenders in the not too long and complicated procedures. Most creditors will choose finance that offers low mortgage interest. People usually also choose a bank that will finance the purchase of the car, which is the same bank as the bank that serves as a container and primary distribution of income that it generates.

The conditions indicate how strong the cultural transformation that has occurred in the community, especially the behavior of instant culture, people want everything filled up quickly, get things done quickly, served too quickly. Meanwhile, the economic actor, entrepreneurs respond swiftly to the needs of the community (Yoga \& Paramartha, 2018). This has triggered a highly competitive competition among dealers, marketing, and corporate finance, various ways they use other than personal selling, also put adverts in the print media. Almost all of the daily newspaper advertisements of the marketing mini car dealer, with a variety of taglines to convince potential customers. Briefly stated if the instant culture that embraced the community due to globalization in all spheres of life practiced changing consumer behavior in buying a car that is very hedonist. Consumer society is based on internal factors do because it was in him, which can also come from external factors outside himself. Internal factors are private factors, according to Kotler \& Keller (2009), include, age, life cycle stage, occupation, economic circumstances, lifestyle, personality, and concepts. Internal factors are strongly associated with external factors, if one refers to the Consumer Behavior Theory of Kotler \& Keller (2009), covering the reference group, the family, the role and status.

Related to this study, which serves as the reference group could come from marketing who joined the company's dealers, co-workers who often affects so informant decided to buy a new car, or idol, commercials that became iconic products of the latest car. In addition to referring to the theory of consumer behavior, cultural transformation in the consumer society is also very consistent with the concept of transformation global culture described by Martyn (2006), that the birth of culture is expressed through the act of aesthetic and cultural practices are typically reflected in the selection of vehicles, conditioned as part of fashion products to support the physical appearance. Side of hedonism which in essence is the desire to have something reflected in the behavior of the consumer society. Although classified as a luxury item, but this time make purchases of consumer society is like a car to buy clothes and other fashion products, which is highly influenced by trends and fashion.

Subawa, N. S., Widhiasthini, N. W., Pika, P. A. T. P., \& Suryawati, P. I. (2020). Hedonism on the behavior of consumer society as a global cultural transformation. International Research Journal of Management, IT and Social Sciences, 7(2), 59-70. https://doi.org/10.21744/irjmis.v7n2.878 


\section{Conclusion}

Referring to the description in the discussion can be concluded that the practical realities of hedonism occurred in people's behavior, especially in the consumer behavior buying a new car can be seen from the profession are not limited to a particular profession. In terms of old age, in general, they are well-established and fixed income. Various reasons people who purchase new cars, such as the wish to enjoy the advanced features offered by producers, prestige or other reasons.

Social change has occurred in the behavior of consumerist society, where they bought a car by making use of the credit system offered in cooperation with the car dealer finance company. Changes in people's behavior are more common since 2000 because the credit system of society gets various bonuses from the dealer. At this point, the networks of global capitalism played a role. Although various new sophistication output of cars offered by the seller with an offer of various facilities in the purchase process, people should not easily get stuck, causing behavior that is based on consumerist hedonism desire. People should consider various things before making purchasing practices, especially if you already have the same product. To marketers do not focus on just the pursuit of profits and bonuses alone, but also pay attention to the ability of people, explaining in detail the potential negatives that may occur. Not only explains ideal conditions only, to provide a balance of information. Researchers recognize the need for the next research about research topics such as scrutiny of behavior change consumer society in consuming products other than cars that show the behavior of hedonism, marketing methods most appropriate and powerful conducted by marketing and company car dealers to affect consumer society in the purchase of a car.

\section{Conflict of interest statement}

The authors declared that they have no competing interests.

\section{Statement of authorship}

The authors have a responsibility for the conception and design of the study. The authors have approved the final article.

\section{Acknowledgments}

We are grateful to two anonymous reviewers for their valuable comments on the earlier version of this paper. 


\section{References}

Bappenas, Directorate of Macro Planning. (2011). Konsumsi Rumah Tangga.

Büttner, O. B., \& Göritz, A. S. (2008). Perceived trustworthiness of online shops. Journal of Consumer Behaviour: An International Research Review, 7(1), 35-50. https://doi.org/10.1002/cb.235

Central Bureau of Statistics. (2015). Selayang Pandang Kota Denpasar.

GÃ $1 / 4$ ltekin, B. (2012). The influence of hedonic motives and browsing on impulse buying. Journal of Economics and Behavioral Studies, 4(3), 180-189. https://doi.org/10.22610/jebs.v4i3.315

Godey, B., Pederzoli, D., Aiello, G., Donvito, R., Wiedmann, K. P., \& Hennigs, N. (2013). A cross-cultural exploratory content analysis of the perception of luxury from six countries. Journal of Product \& Brand Management. https://doi.org/10.1108/JPBM-02-2013-0254

Hirschman, E. C., \& Holbrook, M. B. (1982). Hedonic consumption: emerging concepts, methods and propositions. Journal of marketing, 46(3), 92-101. https://doi.org/10.1177\%2F002224298204600314

Ibrahim, I. S. (2004). Sirnanya komunikasi empatik: krisis budaya komunikasi dalam masyarakat kontemporer. Pustaka Bani Quraisy: Forum Indonesia untuk Komunikasi tanpa Kekerasan (Fiskontak).

Jain, S. (2019). Factors affecting sustainable luxury purchase behavior: A conceptual framework. Journal of International Consumer Marketing, 31(2), 130-146. https://doi.org/10.1080/08961530.2018.1498758

Jee Han, Y., Joseph, C. N., \& Xavier, D. (2010). Signaling Status with Luxury Goods: The Role of Brand Promonence. Journal of Marketing, 74(4), 15-30.

Kastanakis, M. N., \& Balabanis, G. (2012). Between the mass and the class: Antecedents of the "bandwagon" luxury consumption behavior. Journal of Business Research, 65(10), 1399-1407. https://doi.org/10.1016/j.jbusres.2011.10.005

Kleden, H. (2014). September Penjualan Mobil di Bali Meningkat. AutoRevIndonesia.

Kotler, P. \& Keller, K.L. (2009). Marketing Management. Twelfth Edition. New Jersey. Pearson Prentice Hall. Inc.

Kotler, P., \& Keller, K. L. (2009). Marketing management (13th end).

Lim, W. M. (2014). The antecedents and consequences of customer hedonism in hospitality services. Journal of Hospitality Marketing \& Management, 23(6), 626-651. https://doi.org/10.1080/19368623.2014.846838

Loureiro, S. M. C., \& de Araújo, C. M. B. (2014). Luxury values and experience as drivers for consumers to recommend and pay more. Journal of Retailing and Consumer Services, 21(3), 394-400. https://doi.org/10.1016/j.jretconser.2013.11.007

Malone, S., McCabe, S., \& Smith, A. P. (2014). The role of hedonism in ethical tourism. Annals of Tourism Research, 44, 241-254. https://doi.org/10.1016/j.annals.2013.10.005

Mansouri, S. H., \& Taherikia, F. (2015). The Impact of Quality on consumption emotions and Customers behavioral intentions. Asian Journal of Research in Marketing, 4(1), 77-86.

Martyn, J. L. (2006). Budaya Konsumen Terlahir Kembali: Arah baru Modernitas dalam Kajian Modal, Konsumsi, dan Kebudayaan (Consumer Culture Reborn: The Culture Politics of Consumption). Yogyakarta: Kreasi Wacana.

Miles, M. B., \& Huberman, A. M. (1992). Analisis Data Kualitatif. Terjemahan Tjetjep Rohendi Rohidi. Jakarta: Penerbit Universitas Indonesia.

O’Shaughnessy, J. N., O’Shaughnessy. (2002). “Marketing, Consumer Society and Hedonism.” European Journal of Marketing, 36(5/6), 524-547.

Piliang, Y. A. (2011). Dunia yang dilipat: Tamasya melampaui batas-batas kebudayaan. Matahari.

Ratna, N. K. (2007). Sastra dan cultural studies: representasi fiksi dan fakta. Pustaka Pelajar.

Rosyidi, S. (2006). Pengantar Teori Ekonomi Pendekatan Kepada Teori Ekonomi Mikro \& Makro. Jakarta: Rajawali Pers.

Schade, M., Hegner, S., Horstmann, F., \& Brinkmann, N. (2016). The impact of attitude functions on luxury brand consumption: An age-based group comparison. Journal of business research, 69(1), 314-322. https://doi.org/10.1016/j.jbusres.2015.08.003

Semaan, R. W., Lindsay, V., Williams, P., \& Ashill, N. (2019). The influence of gender roles in the drivers of luxury consumption for women: Insights from the gulf region. Journal of Retailing and Consumer Services, 51, 165-175. https://doi.org/10.1016/j.jretconser.2019.06.006

Shao, W., Grace, D., \& Ross, M. (2019). Consumer motivation and luxury consumption: Testing moderating effects. Journal of Retailing and Consumer Services, 46, 33-44. https://doi.org/10.1016/j.jretconser.2018.10.003

Sheth, N. J. Newman. BI \& Gross. BL (1991). Why we buy what we buy. Journal of Business Research, 22(2), 159170.

Subawa, N. S., Widhiasthini, N. W., Pika, P. A. T. P., \& Suryawati, P. I. (2020). Hedonism on the behavior of consumer society as a global cultural transformation. International Research Journal of Management, IT and Social Sciences, 7(2), 59-70. https://doi.org/10.21744/irjmis.v7n2.878 
Siu, N. Y. M., Kwan, H. Y., \& Zeng, C. Y. (2016). The role of brand equity and face saving in Chinese luxury consumption. Journal of Consumer Marketing. https://doi.org/10.1108/JCM-08-2014-1116

Storey, J. (1996). Cultural Studies and the Study of Popular Culture: Athens. GA: University of Georgia.

Subawa, N. S. (2016). Prestige Pricing Strategy as A Symbol of Social Class on Perfume Products. Jurnal Bisnis dan Manajemen, 17(1), 13-21. http://dx.doi.org/10.24198/jbm.v17i1.2

Subawa, N.S. (2015). "Geliat Hedonisme Era Postmodern" (dalam Ragam Wacana: Bahasa, Sastra, dan Budaya), Editor: Erfiani, Ni Made Diana. Yogyakarta: Pustaka Pelajar. 901-912.

Teimourpour, B., \& Hanzaee, K. H. (2011). The impact of culture on luxury consumption behaviour among Iranian consumers. Journal of Islamic Marketing. https://doi.org/10.1108/17590831111164822

Truong, Y., \& McColl, R. (2011). Intrinsic motivations, self-esteem, and luxury goods consumption. Journal of Retailing and Consumer Services, 18(6), 555-561. https://doi.org/10.1016/j.jretconser.2011.08.004

Widhiasthini, N.W. (2006). Sebuah Fenomena Budaya Bernama Konsumerisme dalam Jurnal Kajian Budaya 3(6), Denpasar: Program S2 dan S3 Kajian Budaya.

Wiedmann, K. P., Hennigs, N., \& Siebels, A. (2007). Measuring consumers' luxury value perception: a cross-cultural framework. Academy of Marketing Science Review, 2007, 1.

Vigneron, F., \& Johnson, L. W. (2004). Measuring perceptions of brand luxury. Journal of brand management, 11(6), 484-506. https://doi.org/10.1057/palgrave.bm.2540194

Yoga, I. M. S., \& Paramartha, I. G. N. D. (2018). Attitude, intention, and consumer behaviour of millennial generation toward location-based SMS advertising. International Research Journal of Management, IT and Social Sciences, 5(6), 60-70. https://doi.org/10.21744/irjmis.v5n6.373

Zhong, J. Y., \& Mitchell, V. W. (2010). A mechanism model of the effect of hedonic product consumption on wellbeing. Journal of Consumer Psychology, 20(2), 152-162. https://doi.org/10.1016/j.jcps.2010.01.001 